\title{
Flipped classroom in the second decade of the Millenia: a Bibliometrics analysis with Lotka's law
}

\author{
Norliza Kushairi $^{1}$ (D) $\cdot$ Aidi Ahmi $^{2}$ (D)
}

Received: 7 November 2020 / Accepted: 1 February 2021/ Published online: 4 March 2021

(C) The Author(s), under exclusive licence to Springer Science+Business Media, LLC part of Springer Nature 2021

\begin{abstract}
This paper aims to examine the current dynamics of the flipped classroom studies and to propose a direction for future research for the field. Using a bibliometric approach, we observe a sample of 1557 documents from the Scopus database to identify research activity on the flipped classroom. The keywords "flipped classroom" and "flipped learning" have been executed in the search query. We presented the earlier stage of research in the flipped classroom, the subsequent trends, publications status based on source title, country and institution and examined citations pattern of the publication. We also discuss the themes based on the occurrences and terms of the keywords, title and abstract of the documents. This paper also predicts the future study in the flipped classroom using Lotka's law. We found that the pattern distribution of the author's contribution fits with the law. We conclude by suggesting a few potential research directions on the flipped classroom. Research on flipped classroom focuses on approaches, strategies and effectiveness perceived by practitioners and learners with relatively less attention on author's contribution and the prediction on their future and sustainable contribution and networking in guaranteeing the survival and expansion of flipped classroom approach for the coming decades.
\end{abstract}

Keywords Active learning · Bibliometrics analysis, Lotka's law · Blended learning · Flipped classroom $\cdot$ Flipped learning

Subject classification codes $\mathrm{I} 29 \cdot \mathrm{P} 36 \cdot \mathrm{O} 33$

Norliza Kushairi

drnk@uum.edu.my

Aidi Ahmi

aidi@uum.edu.my

Extended author information available on the last page of the article 


\section{Introduction}

Flipped learning or flipped classroom is by no means a new idea in pedagogical discourse. Its origins can be found in Western curriculum discourse previously evolved from the concepts and theories of 'constructivism' and 'student-centred' learning (Flumerfelt and Green 2013; Missildine et al. 2013; Tune et al. 2013; Smit et al. 2014). There is now a growing literature locating flipped learning as part of global educational debate and discussion. This kind of conceptual evolution is not unusual in education, and this paper attests to its widespread effect as we head towards the third decade of the twenty-first century. There are a number of important issues that emerge from this broad context of "evolution". However, it is not the aim of this paper to articulate this aspect as the discourse could be found elsewhere.

As aforementioned, the conception of flipped learning could be traced back since Socrates, Plato and Dewey's era within the idea of learner's experience, which became significantly central to planning and developing of the curriculum. One of the remarkable contributions to the widespread advancement in flipped learning is due to the recent educational technology advancement. The avalanche of information, communication and technology (ICT) has steered teachers to advance from their custom job specification. More committed teachers are found to have polished their editing and curating skills using available online resources as their teaching aids. The flipped classroom, which is also called inverted classroom by some scholars, works in such a way that the lecture, which is usually done during class time, is exchanged with homework time. In other words, the lecture is viewed outside class hour while homework or active and student-centred learning strategies are done during class hour.

There are many facets of flipped learning being the central discussion in the literature. In brief, a quick browse and analysis on the titles achieved five categories of discourse on flipped learning: methods used to flip the learning, impact on students' learning, the effectiveness of a flipped classroom, the technology used in the flipped classroom and perceptions of students on the flipped classroom. By and large, in all of the discourse, much literature has documented the successful flipped classroom implementation on students' learning attainment. Numerous methods of flipped learning also have been documented entailing the flexibility of design a flipped learning can take. For instance, Forsey et al. (2013) flipped their class by asking their students to take a nine-module massive online open course (MOOC) in Australian Studies before attending two-hour weekly classes. There are also reports on the effectiveness of using video as a replacement to face-to-face asynchronous lectures such as in the work of Smith and McDonald (2013).

Despite the significance of the flipped classroom, few efforts have been made to obtain data concerning the global scientific output of flipped classroom studies (Yang et al. 2017). In the numerous current methods of reviewing the literature, bibliometric analysis is considered as an accurate and potentially equitable tool for measuring a paper's contribution to knowledge advancement (Yi and Xi 2008; Yang et al. 2013). Bibliometric analysis was widely used to evaluate trends and impact, including publishing countries, study areas, journals and author keywords. (Chen and Ho 2015; Chiu and Ho 2007; Chuang et al. 2007; Dong et al. 2012).

The aim of this study is to analyse the trends and developments with a view to helping researchers understand the perspective of universal flipped classroom research. 
This means to say that there needs to be an analysis that could anticipate the author's contribution in years to come or at present. This analysis works as a heuristic device that could gauge the survival of flipped classroom literature in feeding the practitioners and researchers with updated progress of the pedagogy. A quick glance through the titles and abstracts shows that author's contribution has not been dealt with in detail. Hence, we decided to analyse this aspect in detail to add to the body of knowledge in bibliometric and flipped classroom literature by using Lotka's Law. This study is the first, to the best of our knowledge, to combine a bibliometric analysis with Lotka's Law on flipped classroom or flipped learning.

The following research questions (RQs) are addressed in this study: RQ1: What is the current state of the publication in the flipped classroom? RQ2: What are the current citation patterns of publication on the flipped classroom? RQ3: Which themes involving the flipped classroom are the most popular among scholars? RQ4: What is the authorship pattern of the publication on the flipped classroom, and how does this pattern distribution fit into Lotka's Law? RQ5: What areas involving the flipped classroom need additional studies?

Prior to the analysis, the main search query using: (TITLE("flipped learning" and "flipped classroom" and "bibliometric analysis") was executed to gain some insights on the extent to which this area has been analysed using the bibliometric analysis before. The query turned out three results. A further query was done using google scholar using the same search strings. This circumstance implies a timely effort on carrying out the bibliometric analysis on flipped learning.

Thus far there have been three bibliometric articles on flipped learning; Yang et al. (2017) review the development of flipped learning from the year 2000-2015, while Bhagat and Spector (2018) analysed the results of the 2012-2017 flipped classroom pulled from the Web of Science Core Collection based on their publishing trends (e.g., paper type, language, region, etc.). The last bibliometric article was written by AlShabibi and Al-Ayasra (2019) who studied and evaluated 233 scientific studies within the range of 8 years (2012-2019) in order to identify the effectiveness of flipped classroom. This current study identifies the flipped classroom's main areas and current dynamics and suggests future directions for research.

\section{Methods}

The method of this study is based on the process of how the data have been gathered and filtered through all the way until the final collection of the data is firm and ready to be analysed. Earlier, the topic and scope of the study need to be defined which based on the aim of this study; we want to focus on all the study related to the flipped classroom that is available in the Scopus database. Scopus database has been chosen because of its reputation as the "largest single abstract and indexing database ever built" (Burnham 2006) and the largest searchable citation and abstract literature search list (Ahmi et al. 2019; Falagas et al. 2008; Nwagwu 2007).

The selection of the documents gathered for this study has been constructed based on the research protocol guided as per Fig. 1. The data were extracted from the Scopus database as of 9 December 2019. The following combination of keywords was used: "flipped classroom" or "flipped learning" to identify all the target publications. 


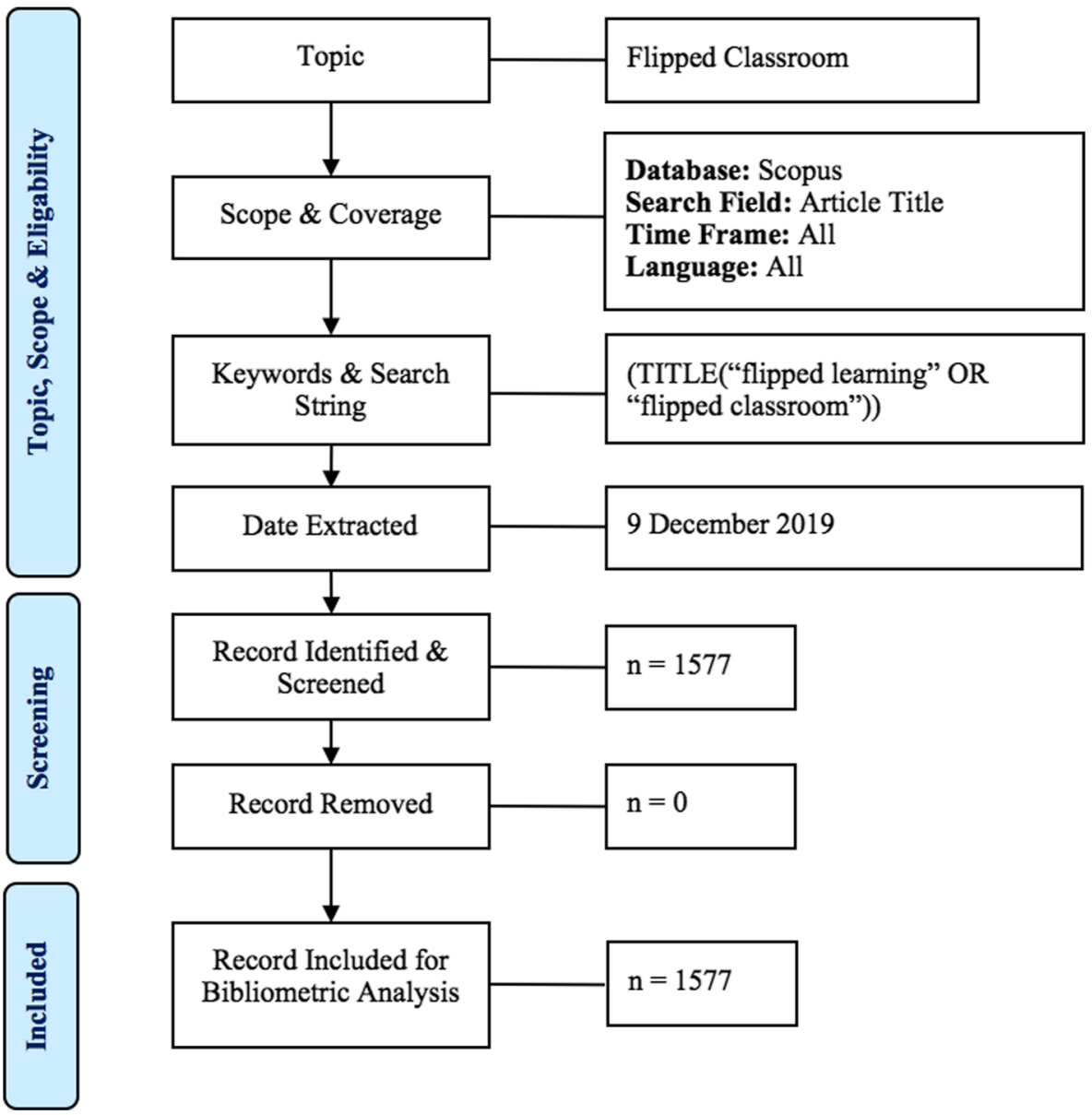

Fig. 1 Research protocol

Considering the sparse effort on bibliometric analysis of flipped classroom, we restricted the documents related to the flipped classroom or flipped learning works based on the title of the document. To achieve this objective, the following query was conducted: (TITLE("flipped learning" OR "flipped classroom")). This query produced a total of 1557 documents. A series of data cleaning done showed no duplicate of the documents; hence the similar number of documents was retained after the process. All the data gathered from the Scopus database then have been exported into comma-separated values (.csv) and research information systems (.ris) formatted files.

This study employed the bibliometric method to analyse all the research trend of flipped classroom research. The database supplies publication details encompassing type, year, language, subject area, source title, keywords, abstract, country, affiliation, citations and authorship of the documents. Microsoft Excel, Harzing's Publish or Perish and VOSviewer software were used for data analysis and data visualisation, respectively. In this study, we use VOSviewer software to perform major portions of the mapping analyses (Bastian et al. 2009; Van Eck and Waltman 2020). VOSviewer uses two uniform weights to graphically represent the nodal network, such as the number 
and overall strength of the connections. The network size and the network-connecting interlinking lines reflect the importance and power of the links.

\section{Results and analysis of findings}

To answer the research questions developed in the previous section, the analysis of this paper employed the following aspects of scholarly works: publication by year, document types, publication by source title, source types, publication by country, the publication by institutions, languages of documents, subject area, citation patterns, themes in flipped classroom based on the keywords and title and abstract, authorship and applicability of Lotka's law. Findings are mostly presented in the format of frequency and percentage. Some of the analyses have been extended by identifying the number of cited publications (NCP), total citations (TC), average citations per publication $(\mathrm{C} / \mathrm{P})$, average citations per cited publication $(\mathrm{C} / \mathrm{CP}), \mathrm{h}$-index, and g-index. For the most active source title, we report the name of the publisher, the current Cite Score, SCImago Journal Rank (SJR) 2018 and Source Normalized Impact per Paper (SNIP) 2018 as per Scopus database. SJR measures weighted citations received by the source title, while SNIP measures actual citations received relative to citations expected for the source title's subject field. We report citation analysis as citation metrics and disclosed ten most cited articles in the flipped classroom. We also run some statistical analysis of the authorship productivity based on Lotka's law.

\subsection{Current state of publication in flipped classroom}

To answer RQ1 (What is the current state of publication in a flipped classroom?), we analysed the publication trend in the flipped classroom using total publications by year, document type, the publication by source title, type of source title, the publication by country, the publication by the institution, language and subject area of the publication. We used the bibliographic data collected from the Scopus database to calculate the data for that analysis.

\subsubsection{Publication by year}

Table 1 summarises the details statistic of annual publications on flipped classroom/ flipped learning. Based on the Scopus database, there are four articles written in 2012, which marks the verge of the rapid growth of the flipped classroom. The first four earliest papers were written by Tucker (2012), Pierce and Fox (2012), Parslow (2012) and Burns (2012). Further analysis of these papers revealed that three of them are short writings in the form of editorial or note of a newsletter/bulletin. Nevertheless, the number of citations for these papers is 164 , which marks their significant contribution, justified as the pioneers of publications. It is also noteworthy that, except for Tucker's paper, the remaining papers were from Science cluster, i.e. Pharmaceutical, Biochemistry and Medicine. This can be inferred that flipped learning move had been pioneered by pure science genre writers/researchers/practitioners.

In these three Science-based articles, commonalities exist whereby the work reported emphasised on the formative assessment at the biteable size of knowledge 
Table 1 Year of publications

\begin{tabular}{llllllll}
\hline Year & TP & NCP & TC & C/P & C/CP & $h$ & $g$ \\
\hline 2012 & 4 & 4 & 656 & 164 & 164 & 4 & 4 \\
2013 & 28 & 28 & 1830 & 261.43 & 261.43 & 15 & 28 \\
2014 & 84 & 73 & 1998 & 23.79 & 27.37 & 19 & 43 \\
2015 & 209 & 166 & 2961 & 14.17 & 17.84 & 23 & 50 \\
2016 & 234 & 158 & 2017 & 8.62 & 12.77 & 23 & 39 \\
2017 & 292 & 195 & 1716 & 5.88 & 8.80 & 20 & 31 \\
2018 & 366 & 181 & 828 & 2.26 & 4.57 & 13 & 19 \\
2019 & 332 & 84 & 184 & 0.55 & 2.19 & 5 & 8 \\
2020 & 8 & 8 & 0 & 0 & 0 & 0 & 0 \\
Total & 1557 & & & & & & \\
\hline
\end{tabular}

$T P$ total number of publications, $N C P$ number of cited publications, $T C$ total citations, $C / P$ average citations per publication, $C / C P$ average citations per cited publication, $h$ h-index, and $g$ g-index

acquisition deemed to be economical and practical in achieving the learning objectives. The concept of "less is more" is evidenced here. For instance, Pierce and Fox (2012) approached their group of pharmacy students on renal pharmacotherapy via vodcasts before the scheduled class. They designed a process-oriented guided inquiry learning (POGIL) activity whereby students watched video lecture as a pre-class activity. Then, students applied the material contained in the video in an interactive discussion on cases of patients with end-stage renal disease in class. This formative assessment optimising the use of technology advancement to expedite the acquisition of knowledge had witnessed meaningful achievement in student's performance.

While Burns (2012), in his two-page-editorial note, reported on an initiative by a group of intensive care medical instructors at a tertiary care academic centre. These instructors intervened the traditional forth-nightly call schedule intensive care shift with a shift-work that combined an optimal sign-out practices curriculum which Burns had undeniably noted some remarkable features. What Burns advocates at the conclusion of his writing is that by letting a long-off schedule from seeing the students, more provision of educational content via the internet for "asynchronous learning" would allow more time for valuable instructor-led teaching to focus on critical thinking skills. He reviewed this approach as providing the instructor with potentially new and highly sensitive measures to track individual student assessment and guidance. Being visionary, Burns saw this implementation as not inviting any unforeseen hurdles for the trainees, since the internet-based classroom education had always been available to them regardless of their particular shift schedule (Wolbrink and Burns 2012; Prober and Heath 2012).

In a somewhat seemingly different tone, Parslow (2012) penned his voice about Khan's ways of flipping the class on a barely two-page article. He personally tried to make readers think of the other side of learners' favourite Khan's flipped style by asking readers to visualise future education with a flipped approach. For a note written almost 8 years ago, Parslow (2012) had successfully anticipated the flipped-mania's verge of quantum leap beginning the second decade of the millennia. 
While Parslow tapped onto readers' mind on the future avenue of flipped learning, Tucker (2012) reviewed Bergmann and Sams (2012) accidental-encounter of lecture recording - whereby both teachers initially intended to help absenteeism in their class to catch up with the missing lessons- which turned into beneficial self-paced learning or what has been known since the era of constructivists theory, the mastery learning paradigm, for all types of students. On reflection, the flipped classroom approach purports the student-centred strategy, which has long been urged by prominent scholars. In all, through a video-lecture featured flipped learning, the bite-sized lesson to achieve learning objectives is what these articles commonly highlighted.

Hence, by and large, these pioneer articles had set a history for flipped learning when it was cited 164 times. As per records, between 2012 to 2014, the growth of the publication was somewhat slow with only less than $6 \%$ of publication in 2014 . Beginning the year of 2015, a sharp growth was witnessed with $13.42 \%$ articles being published. The trend started to pick up since then, with an average of 250 publications a year. The highest number of publications is observed in 2018, with a total of 366 documents $(23.51 \%)$. This observation signifies the peak period of the trending practice via the flipped classroom approach applied by educators globally (Fig. 2). This situation is understandable when the succeeding analysis was executed, particularly with respect to the trend of countries participating in research.

\subsubsection{Document types}

Document type refers to the type of the document, which can be classified into a few categories such as conference paper, article, book chapter, review, editorial and note. Table 2 summarises the distribution of documents published on flipped learning which falls into 12 document types. Obviously, more than half of all publications were categorised as an article $(52.99 \%)$ followed by a conference paper $(33.46 \%)$. Certain forms of publications accounted for fewer than $14 \%$ of the overall documents (Tables 3 and 4).

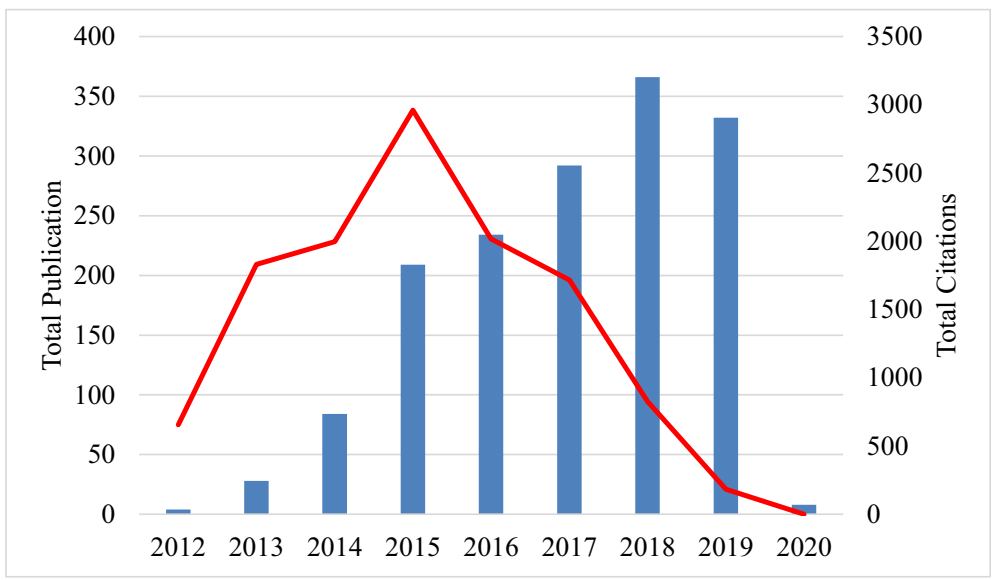

Fig. 2 Publication and citation trend of flipped learning studies 
Table 2 Document type

\begin{tabular}{lll}
\hline Document Type & Total Publications (TP) & Percentage (\%) \\
\hline Article & 825 & 52.99 \\
Conference Paper & 521 & 33.46 \\
Book Chapter & 111 & 7.13 \\
Review & 43 & 2.76 \\
Editorial & 12 & 0.77 \\
Note & 11 & 0.71 \\
Erratum & 7 & 0.45 \\
Letter & 6 & 0.39 \\
Book & 5 & 0.32 \\
Short Survey & 1 & 0.06 \\
Retracted & 1 & 0.06 \\
Undefined & 14 & 0.90 \\
Total & 1557 & 100.00 \\
\hline
\end{tabular}

\subsubsection{Publication by source titles}

In this analysis, once again, a shift from the previous analyses is observed. Previously, Bhagat and Spector (2018) found that the Journal of Chemical Education as the topmost outstanding journal with 17 publications. This is also evidenced in Yang et al. (2013). However, in this analysis, as illustrated in Table 6, it shows that the most active source title comes from American Society of Engineering Education (ASEE) proceedings with 77 publications, followed by ACM International Conference Proceeding Series (33 publications) and Interactive Learning Environments (27 publications). Journal of Chemical Education comes the fourth with 19 publications within roughly 10 years between 2012-early 2020. The observations indicated that flipped classroom applications are gaining more attention in educational engineering education.

\subsubsection{Source type}

The source type is measured based on the category of source title presented in the previous section. It can be classified into journal, conference proceedings, book series, book or trade publication. It is a little bit different compared to the document type. For example, the conference paper that appears under document type may be different than those that appear under the source type (Sweileh et al. 2017). While the document type is measured based on the document itself, the source type is measured based on the source title.

Table 4 shows the categorisation of the source title, which can be classified into four types. Distinctively, journal represents the highest type of source with 921 documents (59.15\%), followed by conference proceedings of 457 publications (29.35\%). Book series also contribute quite significantly at $4.62 \%$ ( 72 documents) to the total number of 
Table 3 Most active source title

\begin{tabular}{|c|c|c|c|c|c|c|}
\hline Source Title & $\mathrm{TP}$ & $\mathrm{TC}$ & Publisher & $\begin{array}{l}\text { Cite } \\
\text { Score }\end{array}$ & $\begin{array}{l}\text { S J R } \\
2018\end{array}$ & $\begin{array}{l}\text { SNIP } \\
2018\end{array}$ \\
\hline $\begin{array}{l}\text { ASEE Annual Conference and Exposition } \\
\text { Conference Proceedings }\end{array}$ & 77 & 856 & $\begin{array}{l}\text { American Society for } \\
\text { Engineering } \\
\text { Education }\end{array}$ & N/A & N/A & N/A \\
\hline ACM International Conference Proceeding Series & 33 & 34 & $\begin{array}{l}\text { Association for } \\
\text { Computing } \\
\text { Machinery }\end{array}$ & N/A & N/A & N/A \\
\hline Interactive Learning Environments & 27 & 69 & Taylor \& Francis & 2.44 & 0.9 & 1.252 \\
\hline Journal of Chemical Education & 19 & 405 & $\begin{array}{l}\text { American Chemical } \\
\text { Society }\end{array}$ & 1.78 & 0.464 & 1.099 \\
\hline $\begin{array}{l}\text { Blended Learning Concepts Methodologies Tools } \\
\text { and Applications }\end{array}$ & 18 & 1 & IGI Global & N/A & $\mathrm{N} / \mathrm{A}$ & $\mathrm{N} / \mathrm{A}$ \\
\hline $\begin{array}{l}\text { Lecture Notes in Computer Science Including } \\
\text { Subseries Lecture Notes in Artificial } \\
\text { Intelligence and Lecture Notes in } \\
\text { Bioinformatics }\end{array}$ & 18 & 38 & Springer Nature & 1.06 & 0.283 & 0.713 \\
\hline Educational Technology and Society & 17 & 332 & $\begin{array}{l}\text { Educational } \\
\text { Technology and } \\
\text { Society }\end{array}$ & 3.53 & 1.085 & 1.995 \\
\hline British Journal of Educational Technology & 16 & 210 & Wiley-Blackwell & 4.07 & 1.419 & 2.354 \\
\hline Computers and Education & 15 & 492 & Elsevier & 7.72 & 2.323 & 3.797 \\
\hline $\begin{array}{l}\text { International Journal of Emerging Technologies } \\
\text { in Learning }\end{array}$ & 15 & 43 & $\begin{array}{l}\text { Kassel University Press } \\
\text { GmbH }\end{array}$ & 0.97 & 0.219 & 0.819 \\
\hline Journal of Physics Conference Series & 15 & 0 & $\begin{array}{l}\text { Institute of Physics } \\
\quad \text { Publishing }\end{array}$ & 0.51 & 0.221 & 0.454 \\
\hline $\begin{array}{l}\text { Proceedings Frontiers in Education Conference, } \\
\text { FIE }\end{array}$ & 15 & 136 & $\begin{array}{l}\text { Institute of Electrical } \\
\text { and Electronics } \\
\text { Engineers Inc. }\end{array}$ & 0.43 & 0.155 & 0.503 \\
\hline $\begin{array}{l}\text { Proceedings of The European Conference on E } \\
\text { Learning Ecel }\end{array}$ & 14 & 10 & $\begin{array}{l}\text { Academic Conferences } \\
\text { Limited }\end{array}$ & N/A & N/A & N/A \\
\hline Boletin Tecnico Technical Bulletin & 13 & 5 & $\begin{array}{l}\text { Universidad Central de } \\
\text { Venezuela }\end{array}$ & 0.00 & 0.102 & 0.101 \\
\hline Journal of Advanced Oxidation Technologies & 13 & & Walter de Gruyter & 0.88 & 0.274 & 0.316 \\
\hline BMC Medical Education & 12 & 176 & Springer Nature & 2.17 & 0.802 & 1.358 \\
\hline Computer Applications in Engineering Education & 12 & 71 & Wiley-Blackwell & 1.90 & 0.395 & 1.418 \\
\hline $\begin{array}{l}\text { Communications in Computer and Information } \\
\text { Science }\end{array}$ & 11 & 15 & Springer Nature & 0.46 & 0.168 & 0.385 \\
\hline ACS Symposium Series & 10 & 9 & $\begin{array}{l}\text { American Chemical } \\
\text { Society }\end{array}$ & 0.51 & 0.212 & 0.242 \\
\hline Advances in Intelligent Systems and Computing & 10 & 6 & Springer Nature & 0.54 & 0.174 & 0.434 \\
\hline American Journal of Pharmaceutical Education & 10 & 415 & $\begin{array}{l}\text { American Association } \\
\text { of Colleges of } \\
\text { Pharmacy }\end{array}$ & 1.22 & 0.630 & 1.099 \\
\hline $\begin{array}{l}\text { Curriculum Design and Classroom Management } \\
\text { Concepts Methodologies Tools and } \\
\text { Applications }\end{array}$ & 10 & 3 & IGI Global & N/A & N/A & N/A \\
\hline Education and Information Technologies & 10 & 58 & Springer Nature & 2.19 & 0.598 & 1.395 \\
\hline
\end{tabular}


Table 3 (continued)

\begin{tabular}{lcccccc}
\hline Source Title & TP & TC & Publisher & Cite & S JR & SNIP \\
& & & & Score & 2018 & 2018 \\
\hline Journal of Computer Assisted Learning & 10 & 48 & Wiley-Blackwell & 4.11 & 1.382 & 2.267 \\
\hline
\end{tabular}

$T P$ total number of publications, TC total citations, SJR SCImago Journal Rank measures weighted citations received by the source title, SNIP Source Normalized Impact per Paper measures actual citations received relative to citations expected for the source title's subject field

the publications. This result suggests that in the second decade of the millennium, there is a steady growth of interest among practitioners and scholars in applying and investigating flipped classroom.

\subsubsection{Publication by country}

There are 26 countries recorded as the most productive countries (see Table 5). Five Asian countries are ranked in the top 10, including Malaysia (47 publications). The top on the list is the United States with a total of 471 (30.25\%) documents followed by China (201: 12.91\%) and Taiwan (127: 8.16\%). Having the United States as the dominating the publication is not surprising as the flipped classroom was originated from this country as early as in the year 2000 (Lage and Platt 2000). This observation can also be related to Table 6 by which the most active resource title is depicted. Exemplifying this is the American Society of Engineering Education (ASEE) whereby a further search on ASEE web revealed that ASEE alone contributed 820 articles in the proceedings since 1996. If the publication is taken between 2012 and 2020, a number of 714 articles came from this source.

Another example is the ConfChem Conference on Flipped Classroom which took place in 2014, featuring eight papers and a poster session exploring a number of methods of engaging students in a flipped classroom (Luker et al. 2015). Some countries or territories, in comparison, reported fewer scientific articles during the study period. This analysis shows a shift from being centralised in the United Statesbased institutions between 2000 and 2015, to Asian-based institutional between 2012 and 2020. As the flipped classroom is closely related to technological distribution, it can be inferred that these developing countries like Taiwan, Hongkong and Malaysia have a relative educational technology advancement rather.

Table 4 Source type

\begin{tabular}{lll}
\hline Source Type & Total Publications (TP) & Percentage (\%) \\
\hline Journals & 921 & 59.15 \\
Conference Proceedings & 457 & 29.35 \\
Books & 107 & 6.87 \\
Book Series & 72 & 4.62 \\
Total & 1557 & 100.00 \\
\hline
\end{tabular}


Table 5 Top publishing countries on flipped classroom

\begin{tabular}{|c|c|c|c|c|c|c|c|}
\hline Country & $\mathrm{TP}$ & $\mathrm{NCP}$ & $\mathrm{TC}$ & $\mathrm{C} / \mathrm{P}$ & $\mathrm{C} / \mathrm{CP}$ & $h$ & $g$ \\
\hline United States & 471 & 340 & 7404 & 15.73 & 21.79 & 41 & 77 \\
\hline China & 201 & 90 & 367 & 1.83 & 4.08 & 9 & 14 \\
\hline Taiwan & 127 & 87 & 1177 & 9.27 & 13.53 & 20 & 32 \\
\hline Australia & 77 & 55 & 1623 & 21.08 & 29.51 & 16 & 40 \\
\hline Spain & 64 & 39 & 246 & 3.84 & 6.31 & 7 & 13 \\
\hline South Korea & 58 & 36 & 209 & 3.60 & 5.81 & 7 & 12 \\
\hline Hong Kong & 51 & 33 & 520 & 10.20 & 15.76 & 11 & 22 \\
\hline Turkey & 50 & 29 & 353 & 7.06 & 12.17 & 10 & 18 \\
\hline United Kingdom & 48 & 34 & 386 & 8.04 & 11.35 & 8 & 19 \\
\hline Malaysia & 47 & 25 & 201 & 4.28 & 8.04 & 7 & 13 \\
\hline Japan & 37 & 20 & 61 & 1.65 & 3.05 & 4 & 6 \\
\hline Indonesia & 32 & 12 & 113 & 3.53 & 9.42 & 3 & 10 \\
\hline Canada & 30 & 19 & 333 & 11.10 & 17.53 & 8 & 18 \\
\hline Thailand & 28 & 13 & 30 & 1.07 & 2.31 & 3 & 4 \\
\hline India & 23 & 11 & 47 & 2.04 & 4.27 & 4 & 6 \\
\hline Germany & 20 & 13 & 85 & 4.25 & 6.54 & 3 & 9 \\
\hline Norway & 20 & 16 & 223 & 11.15 & 13.94 & 9 & 14 \\
\hline Sweden & 20 & 14 & 117 & 5.85 & 8.36 & 6 & 10 \\
\hline Brazil & 17 & 12 & 287 & 16.88 & 23.92 & 4 & 16 \\
\hline Italy & 14 & 3 & 7 & 0.5 & 2.33 & 2 & 2 \\
\hline Saudi Arabia & 14 & 6 & 111 & 7.93 & 18.50 & 4 & 10 \\
\hline Russian Federation & 13 & 9 & 31 & 2.38 & 3.44 & 3 & 5 \\
\hline Colombia & 12 & 5 & 28 & 2.33 & 5.60 & 3 & 5 \\
\hline Denmark & 10 & 6 & 30 & 3.00 & 5.00 & 4 & 5 \\
\hline Greece & 10 & 6 & 80 & 8.00 & 13.33 & 4 & 8 \\
\hline Singapore & 10 & 7 & 186 & 18.60 & 26.57 & 6 & 10 \\
\hline
\end{tabular}

$T P$ total number of publications, $N C P$ number of cited publications, $T C$ total citations, $C / P$ average citations per publication, $C / C P$ average citations per cited publication, $h$ h-index, and $g$ g-index

\subsubsection{Publication by institution}

Table 6 depicts the three top institutions from Asian countries which contributed to 63 publications (4.05\%). Previously, Yang et al. (2017) reported that between 2000 and 2015, nine most productive institutions were from the United States, and only one was from China. This development shows a drastic increment of awareness in flipped classroom application in Asian countries, particularly in Hongkong and Taiwan. It is also noteworthy that, Malaysia being the developing country in Asia, listed two of its institutions in the topmost influential institutions with a minimum of ten publications. When institutions were ranked according to h-index, the University of Hong Kong, National Taiwan Normal University and the University of North Carolina at Chapel Hill are the top three institutions that lead the publications on flipped learning. 
Table 6 Institutions most commonly affiliated with flipped classroom publications

\begin{tabular}{|c|c|c|c|c|c|c|c|c|}
\hline Affiliation & Country & $\mathrm{TP}$ & $\mathrm{NCP}$ & $\mathrm{TC}$ & $\mathrm{C} / \mathrm{P}$ & $\mathrm{C} / \mathrm{CP}$ & $h$ & $g$ \\
\hline The University of Hong Kong & Hong Kong & 24 & 16 & 229 & 9.54 & 14.31 & 7 & 15 \\
\hline $\begin{array}{l}\text { National Taiwan University of Science } \\
\text { and Technology }\end{array}$ & Taiwan & 23 & 17 & 318 & 13.83 & 18.71 & 6 & 17 \\
\hline National Taiwan Normal University & Taiwan & 16 & 13 & 246 & 15.38 & 19.92 & 7 & 15 \\
\hline $\begin{array}{l}\text { The University of North Carolina at } \\
\text { Chapel Hill }\end{array}$ & United States & 14 & 12 & 691 & 49.36 & 57.58 & 7 & 14 \\
\hline Huazhong Normal University & China & 13 & 8 & 21 & 1.62 & 2.63 & 3 & 4 \\
\hline Universiti Teknologi Malaysia & Malaysia & 13 & 9 & 49 & 3.77 & 4.22 & 5 & 6 \\
\hline Universiti Sains Malaysia & Malaysia & 11 & 5 & 13 & 1.18 & 2.60 & 2 & 3 \\
\hline The Education University of Hong Kong & Hong Kong & 10 & 6 & 199 & 19.9 & 33.17 & 5 & 10 \\
\hline Monash University & Australia & 10 & 7 & 441 & 44.10 & 63.00 & 5 & 10 \\
\hline
\end{tabular}

$T P$ total number of publications, $N C P$ number of cited publications, $T C$ total citations, $C / P$ average citations per publication, $C / C P$ average citations per cited publication, $h$ h-index, and $g$ g-index

\subsubsection{Languages of documents}

There are 14 languages used for publications including Turkish and Croatian. The use of a broad spectrum of languages in publications, which can be considered as major languages, shows the spread and the breadth of nations doing flipped classroom research. The most written language is English (96.47\%) as depicted in Table 7.

Table 7 Languages used for publications

\begin{tabular}{lll}
\hline Language & Total Publications (TP) & Percentage $(\%)$ \\
\hline English & 1502 & 96.47 \\
Spanish & 31 & 1.99 \\
Chinese & 8 & 0.51 \\
Russian & 6 & 0.39 \\
Italian & 5 & 0.32 \\
German & 4 & 0.26 \\
Portuguese & 4 & 0.26 \\
French & 3 & 0.19 \\
Turkish & 3 & 0.19 \\
Croatian & 2 & 0.13 \\
Japanese & 2 & 0.13 \\
Japanese & 2 & 0.13 \\
Korean & 2 & 0.13 \\
Finnish & 1 & 0.06 \\
Total & 1573 & 100.00 \\
\hline
\end{tabular}

*17 documents have been prepared in dual languages 


\subsubsection{Subject area}

Based on all the documents gathered from the Scopus database, flipped learning covers almost all subject areas indicating a great diversity related to the research topic of the flipped classroom in Scopus. Table 8 shows that between this period (2012-2020), the most written subject in flipped learning is social sciences $(37.69 \%)$. This data shows a shift in trend since the last bibliometric analyses done in 2015 and 2017. In 2017, Bhagat and Spector (2018) who did a bibliometric analysis in the period of 6 years between 2012 and 2017, found that 55 out of 115 articles from top 15 journals publishing flipped learning articles came from health care and medical research field. While in 2017, Yang et al. (2017), who did a bibliometric analysis within the year 2000-2015 (in the period of 16 years) had found that educational research, chemistry and medical as the top three categories in the flipped classroom.

Table 8 Subject area

\begin{tabular}{|c|c|c|}
\hline Subject Area & Total Publications (TP) & Percentage $(\%)$ \\
\hline Social Sciences & 1013 & 37.69 \\
\hline Computer Science & 575 & 21.39 \\
\hline Engineering & 355 & 13.21 \\
\hline Medicine & 117 & 4.35 \\
\hline Mathematics & 90 & 3.35 \\
\hline Arts and Humanities & 60 & 2.23 \\
\hline Chemistry & 60 & 2.23 \\
\hline Nursing & 54 & 2.01 \\
\hline Business, Management and Accounting & 47 & 1.75 \\
\hline Physics and Astronomy & 37 & 1.38 \\
\hline Materials Science & 33 & 1.23 \\
\hline Decision Sciences & 31 & 1.15 \\
\hline Psychology & 31 & 1.15 \\
\hline Biochemistry, Genetics and Molecular Biology & 26 & 0.97 \\
\hline Pharmacology, Toxicology and Pharmaceutics & 24 & 0.89 \\
\hline Health Professions & 22 & 0.82 \\
\hline Agricultural and Biological Sciences & 20 & 0.74 \\
\hline Chemical Engineering & 19 & 0.71 \\
\hline Energy & 19 & 0.71 \\
\hline Environmental Science & 19 & 0.71 \\
\hline Economics, Econometrics and Finance & 14 & 0.52 \\
\hline Dentistry & 10 & 0.37 \\
\hline Neuroscience & 6 & 0.22 \\
\hline Earth and Planetary Sciences & 2 & 0.07 \\
\hline Veterinary & 2 & 0.07 \\
\hline Multidisciplinary & 1 & 0.04 \\
\hline Undefined & 1 & 0.04 \\
\hline
\end{tabular}


The current study conducting analysis for the second decade of the new millennium (2012-2020) finds a remarkable shift by which social science has dominated nearly $38 \%$ of the flipped learning publication, followed by computer science $(21.39 \%)$, engineering (13.21) and medicine (4.35). This shows that flipped learning is gaining popularity in the social sciences area, which was not previously obvious and evident in the literature. Increasing studies on educational methods and theories could explain the dominant role of social science research. The comparison between traditional and flipped, in terms of the benefits and strategies, technologies including podcasts and video application (McDonald and Smith 2013), the flexibility of the flipped models were among variables studied. Overall, social science research, which seemed slow at picking up the advantage of flipped learning in the first decade of the millennium, is accelerating in terms of its research and application as witnessed in this bibliometric analysis.

\subsection{Citations pattern on flipped classroom}

Our second RQ (What are the current citation patterns of publication on the flipped classroom?) aims to identify the most influential articles on the flipped classroom and visualise the citation pattern of publications from the data that we have gathered from the Scopus database. To answer RQ2, we presented the citation metrics and analysed the citation networks of 1557 articles. In citation analysis, we measure the impact of the documents on the flipped classroom using the number of citations by other works (Baker et al. 2020). We used Harzing's Publish and Perish and VOSviewer software to analyse the data.

The citation metrics for the documents retrieved as of 21 November 2019 are presented in Table 9. As indicated, for 1557 articles retrieved, there is an average of 1524 citations/year, and 12,190 citations reported.

Meanwhile, Table 10 shows the total number of citations with average citation per year for all retrieved documents. It discloses ten most cited articles (based on the number of times being cited) as reported by Scopus. The document entitled "The flipped classroom: A survey of the research" by Bishop and Verleger (2013) has so far

Table 9 Citations metrics

\begin{tabular}{ll}
\hline Metrics & Data \\
\hline Publication years & $2012-2020$ \\
Citation years & 8 \\
Papers & 1557 \\
Citations & 12,190 \\
Citations/year & 1523.75 \\
Citations/paper & 7.83 \\
Papers/author & 512.53 \\
Authors/paper & 2.76 \\
h-index & 48 \\
g-index & 89 \\
\hline
\end{tabular}


Table 10 Top-10 highly cited articles

\begin{tabular}{|c|c|c|c|c|c|}
\hline No. & Author (Year) & Title & Source & $\mathrm{TC}$ & $\mathrm{C} / \mathrm{Y}$ \\
\hline 1 & $\begin{array}{l}\text { Bishop and } \\
\text { Verleger } \\
(2013)\end{array}$ & The flipped classroom: A survey of the research & $\begin{array}{l}\text { 120th ASEE Annual } \\
\text { Conference and } \\
\text { Exposition }\end{array}$ & 673 & 96.14 \\
\hline 2 & $\begin{array}{l}\text { O'Flaherty } \\
\text { and } \\
\text { Phillips } \\
\text { (2015) }\end{array}$ & $\begin{array}{l}\text { The use of flipped classrooms in higher } \\
\text { education: A scoping review }\end{array}$ & $\begin{array}{l}\text { Internet and Higher } \\
\text { Education }\end{array}$ & 471 & 94.2 \\
\hline 3 & $\begin{array}{l}\text { McLaughlin } \\
\text { et al. } \\
\text { (2014) }\end{array}$ & $\begin{array}{l}\text { The flipped classroom: A course redesign to } \\
\text { foster learning and engagement in a health } \\
\text { professions school }\end{array}$ & Academic Medicine & 443 & 73.83 \\
\hline 4 & Tucker (2012) & $\begin{array}{l}\text { The Flipped Classroom: Online instruction at } \\
\text { home frees class time for learning }\end{array}$ & Education Next & 363 & 45.38 \\
\hline 5 & $\begin{array}{l}\text { Abeysekera } \\
\text { and } \\
\text { Dawson } \\
(2015)\end{array}$ & $\begin{array}{l}\text { Motivation and cognitive load in the flipped } \\
\text { classroom: definition, rationale and a call for } \\
\text { research }\end{array}$ & $\begin{array}{l}\text { Higher Education } \\
\text { Research and } \\
\text { Development }\end{array}$ & 338 & 67.6 \\
\hline 6 & $\begin{array}{l}\text { Kim et al. } \\
\quad(2014)\end{array}$ & $\begin{array}{l}\text { The experience of three flipped classrooms in } \\
\text { an urban university: An exploration of } \\
\text { design principles }\end{array}$ & $\begin{array}{l}\text { Internet and Higher } \\
\text { Education }\end{array}$ & 285 & 47.5 \\
\hline 7 & $\begin{array}{l}\text { Pierce and } \\
\quad \text { Fox (2012) }\end{array}$ & $\begin{array}{l}\text { Vodcasts and active-learning exercises in a } \\
\text { "flipped classroom" model of a renal phar- } \\
\text { macotherapy module }\end{array}$ & $\begin{array}{l}\text { American Journal of } \\
\text { Pharmaceutical } \\
\text { Education }\end{array}$ & 268 & 33.5 \\
\hline 8 & $\begin{array}{l}\text { Jensen et al. } \\
\text { (2015) }\end{array}$ & $\begin{array}{l}\text { Improvements from a flipped classroom may } \\
\text { simply be the fruits of active learning }\end{array}$ & $\begin{array}{l}\text { CBE Life Sciences } \\
\text { Education }\end{array}$ & 222 & 44.4 \\
\hline 9 & $\begin{array}{l}\text { Tune et al. } \\
\text { (2013) }\end{array}$ & $\begin{array}{l}\text { Flipped classroom model improves graduate } \\
\text { student performance in cardiovascular, } \\
\text { respiratory, and renal physiology }\end{array}$ & $\begin{array}{l}\text { American Journal of } \\
\text { Physiology - Ad- } \\
\text { vances in Physiology } \\
\text { Education }\end{array}$ & 211 & 30.14 \\
\hline 10 & $\begin{array}{l}\text { Gilboy et al. } \\
\text { (2015) }\end{array}$ & $\begin{array}{l}\text { Enhancing student engagement using the } \\
\text { flipped classroom }\end{array}$ & $\begin{array}{l}\text { Journal of Nutrition } \\
\text { Education and } \\
\text { Behavior }\end{array}$ & 209 & 41.8 \\
\hline
\end{tabular}

$T C$ total citations, $C / Y$ total citations per year

received the highest total of citations (673 citations or an average of 96.14 citations per year).

Another interesting issue regarding the citations is their network visualisation map by countries (see Fig. 3) and by source titles (see Fig. 4). "Citations attribute indicates the number of citations received by a document or the total number of citations received by all documents published by a source, an author, an organisation, or a country" (Van Eck and Waltman 2020). Based on the five minimum number of documents of an author and the five minimum number of citations of an author, a total of 40 countries have met these thresholds. Figure 3 can be read along with the data as per Table 5, which document the number of citations received by each country. We can see that the United States, Taiwan, Australia and Hong Kong were among the countries that received a huge number of citations in flipped learning studies. Taiwan and Australia (in Fig. 3) have been shadowed by the United States circle. 


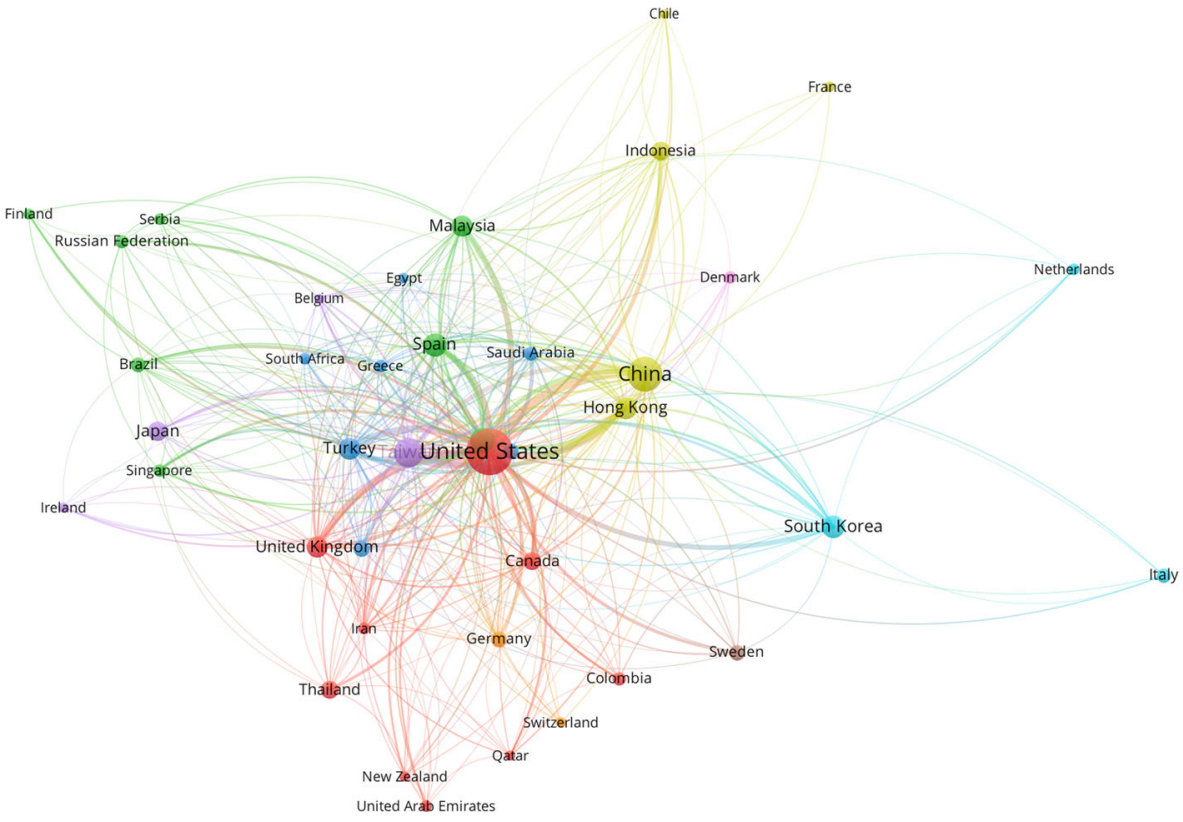

Fig. 3 Network visualisation map of the citation by countries

Additionally, we also can have a look into the citations between source title. Here, the network visualises the source title (such as journals, conference proceedings of books) that cite each other more. The citations represent the sum between the citations that source title A gives to source title B and vice versa. Based on the minimum number of documents of a source title and the minimum number of citations of a source title equal to five, a total of 56 source title have met these thresholds. Figure 4 also can be read along with the data as per Table 3, which document the list of most active source title based on the number of documents produced in flipped learning studies. However, if we analyse the most source title that highly cited, the following source title was the

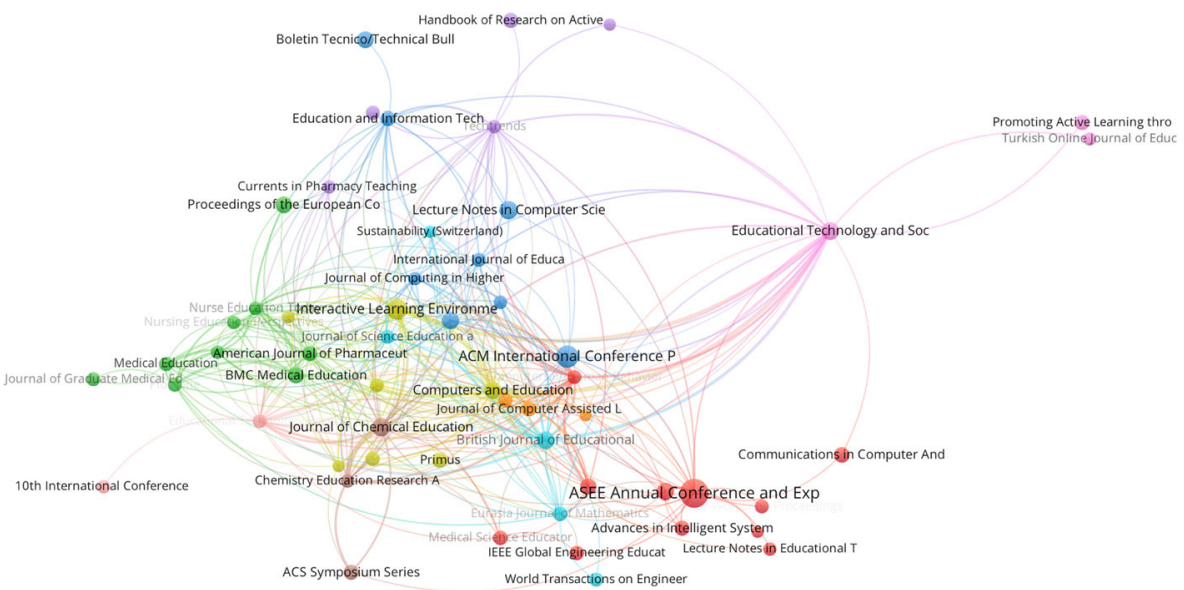

Fig. 4 Network visualisation map of the citation by sources 
top-five source document that highly cited; ASEE Annual Conference and Exposition (856), Conference Proceedings Computers and Education (492), American Journal of Pharmaceutical Education (415), Journal of Chemical Education (405) and Educational Technology and Society (332).

\subsection{Themes in flipped classroom studies}

To answer the RQ3 (Which themes involving flipped classroom are the most popular among scholars?), we analyse the co-occurrence analysis of the keywords and terms from the title and abstract of the data obtained from the Scopus database. Cooccurrence of keywords occurs when two keywords appear together in an article, indicating that there is a relation between the two concepts (Baker et al. 2020). The reason for conducting the co-occurrence and keyword evaluation is that the keywords of an author adequately represent the content of an article (Comerio and Strozzi 2019).

\subsubsection{Keywords}

Undeniably, the author keywords are crucial for researchers to seek research trends. Apart from that, Wen and Huang (2012) advocate that author keyword analysis is also essential for measuring research topic development. After deleting the duplicates occurring from spelling difference (e.g. flipped classroom, flipped classrooms, problem based learning, problem-based-learning), the analysis shows (see Table 11) the most active author keywords in the second decade of the millennium

Further analysis was done by mapping all keywords (which consist of both author keywords and index keywords) supplied for each document using VOSviewer, a software tool for constructing and visualising bibliometric networks (see Fig. 5). In this section, we consider the co-occurrence of each keyword that occurs at least ten times. Based on this threshold, 188 keywords were identified. Fig. 5 shows a network visualisation of all VOSviewer keywords in which the colour, circle size, font size and thickness of the connecting lines indicate the strength of the relationship between keywords (Sweileh et al. 2017). Related keywords, as indicated by the same colour, are commonly listed together. For example, the diagram suggests that flipped classroom, flipped learning, curricula, surveys, artificial intelligence, student engagement, learning management system and all keywords that are in red are closely related and usually co-occur together. Each colour in this figure also represents a cluster. There are four clusters found in this visualisation map. Cluster one (which is coloured in red) consists of 104 items fall under the theme of flipped classrooms. Cluster two (which is coloured in green) consists of 70 items fall under the theme of human. Cluster three (which is coloured in blue) consists of 12 items fall under the theme of nursing education and finally cluster four (which is coloured in yellow) consists of 2 items fall under the theme of student-centred learning.

\subsubsection{Title and abstract}

This paper also has analysed the occurrences of the title of the publications and the combination of both title and abstract of the documents gathered from the Scopus database. In this section, we consider the co-occurrence of each word that occurs at 
Table 11 Top keywords

\begin{tabular}{|c|c|c|}
\hline Author Keywords & Total Publications (TP) & Percentage $(\%)$ \\
\hline Flipped Classroom & 865 & 55.56 \\
\hline Teaching & 548 & 35.20 \\
\hline Students & 540 & 34.68 \\
\hline Education & 398 & 25.56 \\
\hline Human & 213 & 13.68 \\
\hline Problem Based Learning & 193 & 12.40 \\
\hline E-learning & 169 & 10.85 \\
\hline Education Computing & 154 & 9.89 \\
\hline Humans & 151 & 9.70 \\
\hline Engineering Education & 150 & 9.63 \\
\hline Flipped Learning & 143 & 9.18 \\
\hline Learning & 132 & 8.48 \\
\hline Active Learning & 131 & 8.41 \\
\hline Curricula & 130 & 8.35 \\
\hline Procedures & 103 & 6.62 \\
\hline Article & 102 & 6.55 \\
\hline Curriculum & 102 & 6.55 \\
\hline Blended Learning & 92 & 5.91 \\
\hline Higher Education & 86 & 5.52 \\
\hline Learning Systems & 79 & 5.07 \\
\hline Medical Education & 79 & 5.07 \\
\hline Computer Aided Instruction & 78 & 5.01 \\
\hline Female & 73 & 4.69 \\
\hline Male & 73 & 4.69 \\
\hline Human Experiment & 70 & 4.50 \\
\hline Surveys & 65 & 4.17 \\
\hline Controlled Study & 64 & 4.11 \\
\hline Problem Solving & 59 & 3.79 \\
\hline Educational Model & 56 & 3.60 \\
\hline Educational Technology & 55 & 3.53 \\
\hline Motivation & 55 & 3.53 \\
\hline Educational Measurement & 54 & 3.47 \\
\hline Models, Educational & 52 & 3.34 \\
\hline Adult & 51 & 3.28 \\
\hline
\end{tabular}

least ten times. Based on this setting, 691 words were meet the threshold. However, based on this software, for every 691 terms, a relevance score will be calculated. The most appropriate score will be chosen based on this result. The default option is to pick the most appropriate words of $60 \%$. Thus, the number of terms that have been selected where the default number suggested by the software, which is 415 and a co-occurrence 


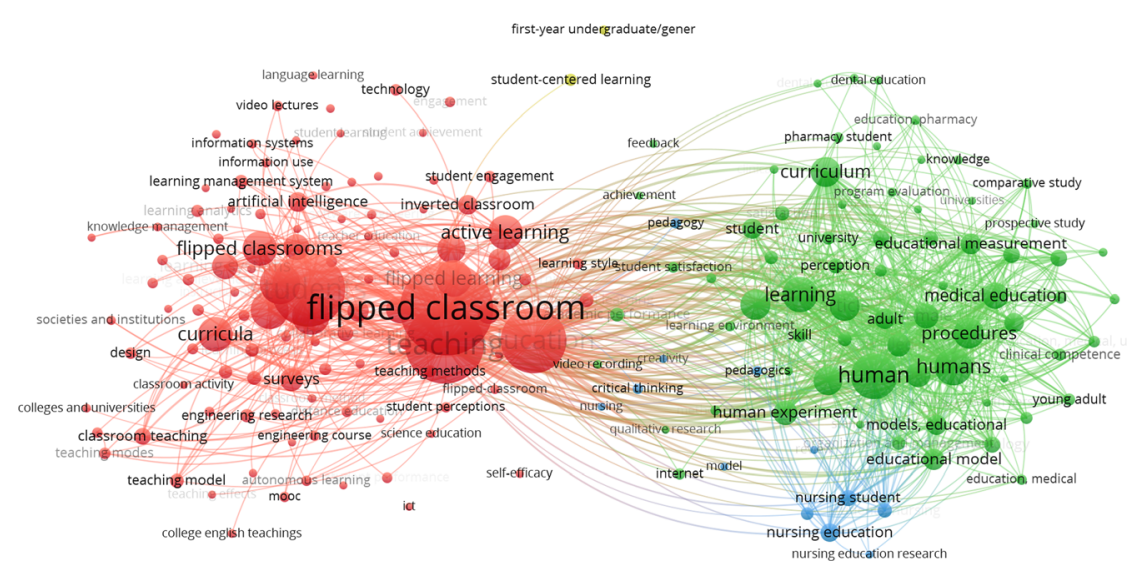

Fig. 5 Network visualisation map of all keywords

map of these words was drawn by VOSviewer software (see Fig. 6). The nodes in this visualisation network represent the terms or concepts, and the distance between them shows the relationship for each term (Sedighi 2016). Each of the colours in this figure represents a cluster. There are five clusters that will represent five themes in this visualisation map. These clusters can be grouped as student engagement group (red 136 items) as theme one, teaching model group (green - 99 items) as theme two, classroom method (blue - 95 items) as theme three, assessment group (yellow - 68 items) as theme four, and completion group (purple - 17 items) as theme five.

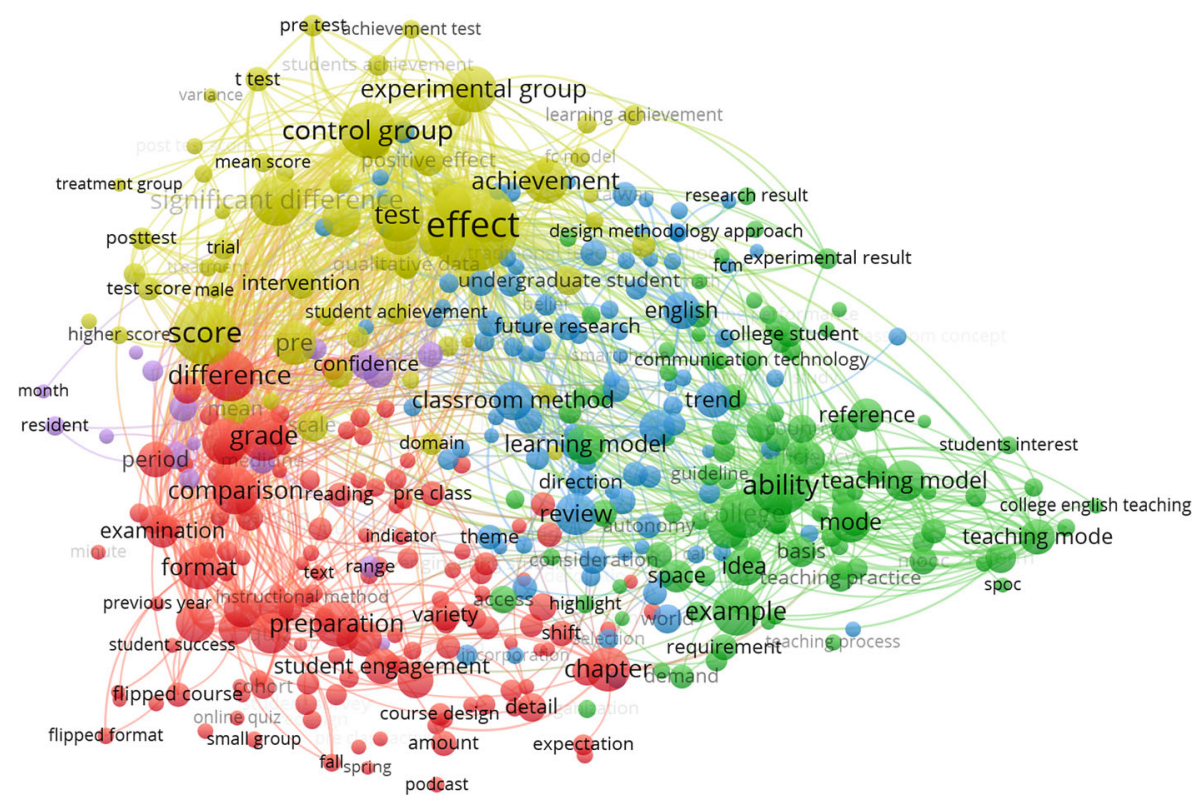

Fig. 6 VOSviewer visualisation of a term co-occurrence network based on title and abstract fields (Binary Counting) 


\subsection{Authorship and applicability of Lotka's law}

To answer RQ4 (What is the authorship pattern of the publication on the flipped classroom and how does this pattern distribution fit into Lotka's Law?), we analysed the number of authors per document, most active authors in the flipped classroom and statistical analysis to test the applicability of Lotka's law on the publication of flipped classroom.

\subsubsection{Authorship analysis}

Table 12 summarises the number of times an individual authored or co-authored a paper. There are $468(30.06 \%)$ documents bi-authored, while $368(23.64 \%)$ are singleauthored and the remaining documents $(721 ; 46.3 \%)$ are reported as multi-authored publications ranging from zero to 21 authors.

Simultaneously, the data was also subjected to a frequency of publishing by a particular author. Table 13 illustrated the most productive authors with a minimum of 6 publications.

Figure 7 displays the network visualisation map between countries in terms of the co-authorship. Based on the minimum number of documents of a country and the minimum number of citations of a country equal to five, a total of 40 countries have met these thresholds. Vividly, United States associates with many countries across the globe as compared to other countries. Again, United States champions the co-

Table 12 Number of author (s) per document

\begin{tabular}{lll}
\hline No. of Author & Total Publications (TP) & Percentage (\%) \\
\hline $0^{*}$ & 5 & 0.32 \\
1 & 368 & 23.64 \\
2 & 468 & 30.06 \\
3 & 320 & 20.55 \\
4 & 185 & 11.88 \\
5 & 109 & 7.00 \\
6 & 49 & 3.15 \\
7 & 21 & 1.35 \\
8 & 10 & 0.64 \\
9 & 12 & 0.77 \\
10 & 1 & 0.06 \\
11 & 2 & 0.13 \\
12 & 5 & 0.32 \\
13 & 1 & 0.06 \\
21 & 1 & 0.06 \\
Total & & 100.00 \\
\hline
\end{tabular}

*No Author ID identified by Scopus 
Table 13 Most productive authors

\begin{tabular}{|c|c|c|c|c|c|c|c|c|c|}
\hline $\begin{array}{l}\text { Author's } \\
\text { Name }\end{array}$ & Affiliation & Country & $\mathrm{TP}$ & $\mathrm{NCP}$ & $\mathrm{TC}$ & $\mathrm{C} / \mathrm{P}$ & $\mathrm{C} / \mathrm{CP}$ & $h$ & $g$ \\
\hline Hwang, G.J. & $\begin{array}{l}\text { National Taiwan University of } \\
\text { Science and Technology }\end{array}$ & Taiwan & 17 & 12 & 270 & 15.88 & 22.5 & 5 & 16 \\
\hline Lo, C.K. & The University of Hong Kong & Hong Kong & 13 & 11 & 210 & 16.15 & 19.09 & 7 & 13 \\
\hline Hew, K.F. & The University of Hong Kong & Hong Kong & 11 & 9 & 201 & 18.27 & 22.33 & 6 & 11 \\
\hline Zaid, N.M. & Universiti Teknologi Malaysia & Malaysia & 9 & 6 & 43 & 4.78 & 7.17 & 5 & 6 \\
\hline Zainuddin, Z. & The University of Hong Kong & Hong Kong & 8 & 5 & 128 & 16 & 25.60 & 4 & 8 \\
\hline Mohamed, $\mathrm{H}$. & Universiti Teknologi Malaysia & Malaysia & 7 & 5 & 32 & 4.57 & 6.40 & 3 & 5 \\
\hline Aris, B. & Universiti Teknologi MARA & Malaysia & 6 & 4 & 31 & 5.17 & 7.75 & 3 & 5 \\
\hline Connor, K.A. & Rensselaer Polytechnic Institute & United States & 6 & 4 & 11 & 1.83 & 2.75 & 2 & 3 \\
\hline Katz, A. & Armstrong State University & United States & 6 & 3 & 5 & 0.83 & 1.67 & 2 & 2 \\
\hline $\begin{array}{l}\text { McLaughlin, } \\
\text { J.E. }\end{array}$ & $\begin{array}{l}\text { The University of North Carolina } \\
\text { at Chapel Hill }\end{array}$ & United States & 6 & 4 & 517 & 86.17 & 129.25 & 4 & 6 \\
\hline Ogden, L. & West Virginia University & United States & 6 & 3 & 14 & 2.33 & 4.67 & 2 & 3 \\
\hline Rahman, A.A. & $\begin{array}{l}\text { Sekolah Berasrama Penuh } \\
\text { Integrasi Selandar }\end{array}$ & Malaysia & 6 & 4 & 31 & 5.17 & 7.75 & 3 & 5 \\
\hline Yu, P.T. & $\begin{array}{l}\text { National Chung Cheng } \\
\text { University }\end{array}$ & Taiwan & 6 & 4 & 9 & 1.5 & 2.25 & 2 & 2 \\
\hline
\end{tabular}

$T P$ total number of publications, NCP number of cited publications, $T C$ total citations, $C / P$ average citations per publication, $C / C P$ average citations per cited publication, $h$ h-index, and $g$ g-index

authorship entailing that the publication and the conferences related to that publication flourish the networking between these countries.

\subsubsection{Applicability of Lotka's law in flipped classroom publications}

To further understand the co-authorship relationship, Lotka's Law is applied to the data. Lotka's law is deemed as one of the famous laws in bibliometric studies (Ahmi et al. 2020). Lotka (1926) defines that the number of authors who make $n$ contributions is about $1 / n^{\text {a }}$ of those who make one contribution, where $a$ is often almost two which connotes a prediction that the number of authors contributing a particular number of papers is inversely proportional to the number of papers contributed. In other words, the law of Lotka explains the scientific productivity and the relation between the authors and the number of their papers by predicting the contribution of an author for a publication. In the study of data, Lotka found the numbers and the unequal distribution of the authors and articles. Thus, he introduced the concept of scientific productivity, i.e., the quantities of papers written during a certain period by individual researchers. Through this concept, he measured the capacity of scientific researchers. His formula is designated as per Eq. 1 where $y$ is the frequency of authors making $x$ contributions each and $C$ is a constant.

$$
x^{2} y=C
$$




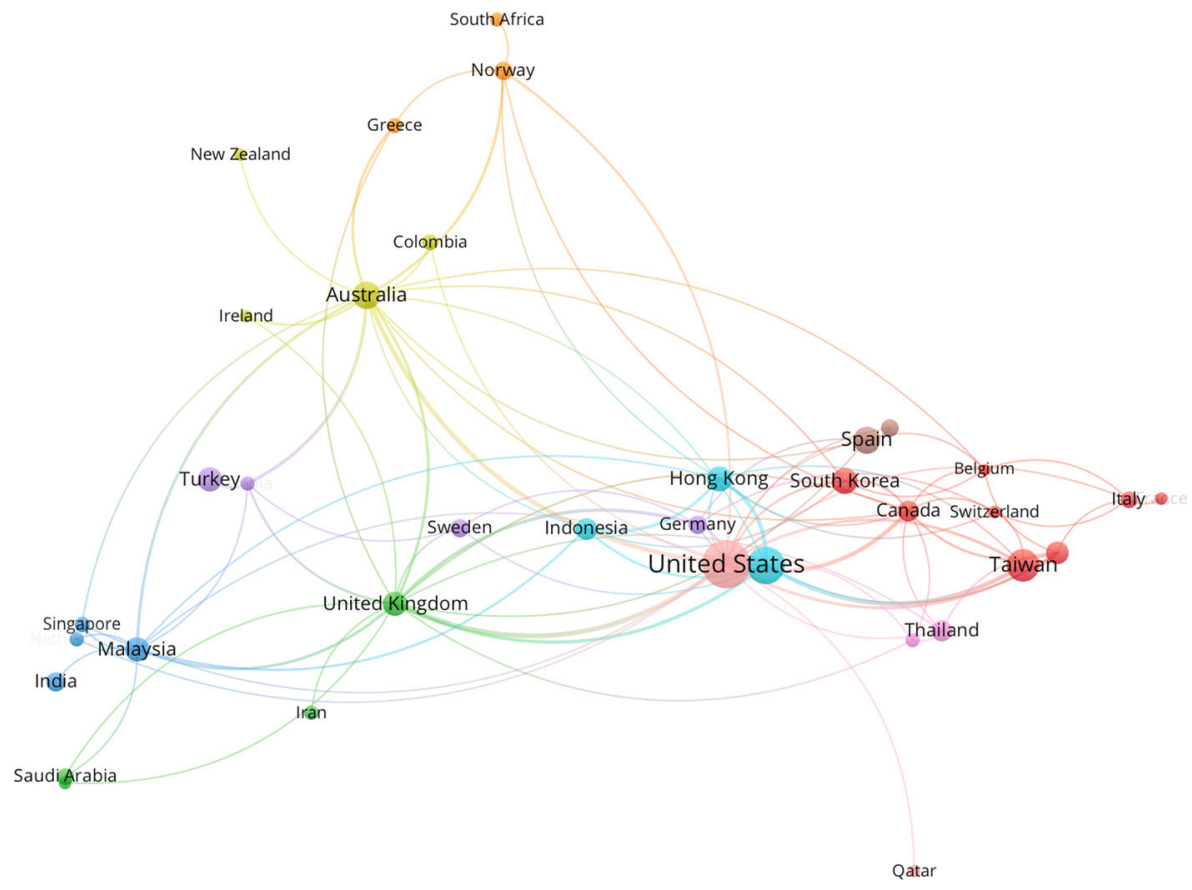

Fig. 7 Network visualisation map of the co-authorship

From the review in the body of literature pertaining to Lotka's law, none was done on Flipped Classroom. Previously, recent studies regarding author productivity patterns were done in marine pollution literature (Rathika et al. 2020), business reporting (Ahmi et al. 2020), supply chain management (Kumar 2019), and biomedical literature (Naheem et al. 2019; Adigwe 2016). What triggered the prediction of productivity patterns and citation by Adigwe (2016), for example, was the scatter and obscurement of the cluster topic in biomedical, despite a holistic view underpinning productivity patterns and citation studies.

In the same demeanour, within the flipped classroom literature, even though the abundance of data is present and accessible on authorship, the pattern and trend of authorship are not yet fully understood. Hence Lotka's Law was employed on the data in this study to predict and comprehend the author's contributions. The following procedures need to be conducted in order to test the applicability of Lotka's law on the authorship productivity in flipped learning studies. Pao (1985), suggest estimating the value of $n, C$ and $C V$ (critical value) in order to test the applicability of Lotka's law.

Calculation of the exponent ' $\boldsymbol{n}$ ' The first step in order to test the applicability of Lotka's law is to determine the value of exponent $n$. The Linear Least Square (LLS) method will be applied by using the formula as per Eq. 2, where $N$ is the number of pairs of data considered, $X$ is the logarithm of $x$ and $Y$ is the logarithm of $y$. 


$$
n=\frac{N \sum X Y-\sum X \sum Y}{N \sum X^{2}-\left(\sum X\right)^{2}}
$$

Based on Table 14, the value of $n$ is calculated as:

$$
n=\frac{12 * 22.32857-20.68490 * 26.66308}{12 * 43.12917-(20.68490)^{2}}=\frac{(283.58)}{89.69}=-3.1619550
$$

Estimation of parameter ' $C$ ' The constant ' $C$ ' can be calculated by the following equation:

$$
C=\frac{1}{\sum \frac{1}{x^{n}}}
$$

Using the value $n=3.1619550$, the value of $C$ can be calculated as:

$$
C=\frac{1}{1.17014}=0.85
$$

Kolmogorov-Smirnov (K-S) statistical Test To test the applicability of Lotka's law, Coile (1977) recommends the K-S statistical test (see Table 15). The maximum

Table 14 Calculation of n-total count method

\begin{tabular}{lllllllll}
\hline No. & $x$ & $y$ & $X$ & $Y$ & $X Y$ & $X^{2}$ & $x^{n}$ & $1 / x^{n}$ \\
\hline 1 & 1 & 3132 & - & 8.04943 & - & - & 1.00000 & 1.00000 \\
2 & 2 & 340 & 0.69315 & 5.82895 & 4.04032 & 0.48045 & 8.95042 & 0.11173 \\
3 & 3 & 65 & 1.09861 & 4.17439 & 4.58603 & 1.20695 & 32.25789 & 0.03100 \\
4 & 4 & 28 & 1.38629 & 3.33220 & 4.61942 & 1.92181 & 80.10998 & 0.01248 \\
5 & 5 & 14 & 1.60944 & 2.63906 & 4.24740 & 2.59029 & 162.22274 & 0.00616 \\
6 & 6 & 7 & 1.79176 & 1.94591 & 3.48660 & 3.21040 & 288.72159 & 0.00346 \\
7 & 7 & 2 & 1.94591 & 0.69315 & 1.34880 & 3.78657 & 470.06942 & 0.00213 \\
8 & 8 & 1 & 2.07944 & - & - & 4.32408 & 717.01778 & 0.00139 \\
9 & 9 & 1 & 2.19722 & - & - & 4.82780 & 1040.57144 & 0.00096 \\
10 & 12 & 1 & 2.48491 & - & - & 6.17476 & 2584.17886 & 0.00039 \\
11 & 13 & 1 & 2.56495 & - & - & 6.57897 & 3328.42508 & 0.00030 \\
12 & 17 & 1 & 2.83321 & - & - & 8.02710 & 7773.63519 & 0.00013 \\
& & & & & & & &
\end{tabular}

$x$ number of publications, $y$ number of authors, $X \log x, Y \log y$ 
Table 15 K-S test on observed and expected distribution of authors

\begin{tabular}{rlllllll}
\hline$x$ & $y$ & $y x / \sum y x$ & $\sum\left(y x / \sum y x\right)$ & $1 / x^{n}$ & $f e=C\left(1 / x^{n}\right)$ & $\sum f e$ & $D_{\max }$ \\
\hline 1 & 3132 & 0.19611 & 0.19611 & 1.00000 & 0.75000 & 0.75000 & $(0.55389)$ \\
2 & 340 & 0.04258 & 0.23868 & 0.17592 & 0.13194 & 0.88194 & $(0.64326)$ \\
3 & 65 & 0.01221 & 0.25089 & 0.06366 & 0.04774 & 0.92968 & $(0.67879)$ \\
4 & 28 & 0.00701 & 0.25790 & 0.03095 & 0.02321 & 0.95290 & $(0.69499)$ \\
5 & 14 & 0.00438 & 0.26229 & 0.01769 & 0.01327 & 0.96616 & $(0.70387)$ \\
6 & 7 & 0.00263 & 0.26492 & 0.01120 & 0.00840 & 0.97456 & $(0.70964)$ \\
7 & 2 & 0.00088 & 0.26579 & 0.00761 & 0.00571 & 0.98027 & $(0.71447)$ \\
8 & 1 & 0.00050 & 0.26630 & 0.00544 & 0.00408 & 0.98435 & $(0.71806)$ \\
9 & 1 & 0.00056 & 0.26686 & 0.00405 & 0.00304 & 0.98739 & $(0.72053)$ \\
12 & 1 & 0.00075 & 0.26761 & 0.00197 & 0.00148 & 0.98887 & $(0.72126)$ \\
13 & 1 & 0.00081 & 0.26842 & 0.00161 & 0.00121 & 0.99008 & $(0.72165)$ \\
17 & 1 & 0.00106 & 0.26949 & 0.00082 & 0.00062 & 0.99069 & $(0.72121)$ \\
\hline
\end{tabular}

$n$ 2.507, $c 0.75, D_{\max } 0.0031, x$ Frequency of papers, $y x$ Relative frequency of authors with $X$ research papers, $y x / \sum y x$ Fraction of observed number of authors, $\sum\left(y x / \sum y x\right)$ Cumulative fraction of observed number of authors, $f e=C\left(1 / x^{n}\right)$ Fraction of expected number of authors, $\Sigma f e$ Cumulative of the theoretical value of authors, $D_{\max }$ Difference between the observed and expected cumulative value of authors

difference value, $D_{\max }$, representing the maximum deviation is identified as -0.55389 . The critical value, to centrality level $\mathrm{a}=0.01$, is calculated according to Nicholls (1986) as:

$$
\begin{gathered}
C V=\frac{1.63}{\left[\sum y_{x}+\left(\sum y_{x} / 10\right)^{\frac{1}{2}}\right]^{\frac{1}{2}}} \\
C V=\frac{1.63}{\left[3593+\left(\frac{3593}{10}\right)^{1 / 2}\right]^{1 / 2}}=0.026969
\end{gathered}
$$

The critical value is obtained as 0.026969 , thus while comparing the actual value $D_{\max },-0.55389$ with critical value 0.026969 , it is found that the actual value of $D_{\max }$ is lower than the critical value $(0.026969)$ at the 0.01 level of significance. Therefore, these data fit Lotka's law with the value $n=$ 3.1619550 .

Chi-square test The next step to check whether the author productivity distribution follows the Lotka's law, the Chi-square test is examined. The results of the analysis are presented in Table 16.

The calculated value of chi-square obtained is 24.99024 , and the critical value at $5 \%$ level of significance is 28.30 . In comparison, it is found that the calculated value of Chi-square is less than the critical value of chi-square. Thus, again it is concluded that the Lotka's law fits the data under study. The statistical tests show that Lotka's law fit the author distribution pattern in 
Table 16 Chi-square test on flipped classroom publications for applicability of Lotka's law

\begin{tabular}{llllll}
\hline No. of Articles & $\begin{array}{l}\text { Observed } \\
\text { No. of Publications } \\
(\mathrm{Fi})\end{array}$ & $\begin{array}{l}\text { Expected } \\
\text { No. of Publications } \\
(\mathrm{Pi})\end{array}$ & Fi-Pi & $(\mathrm{Fi}-\mathrm{Pi})^{2}$ & $\begin{array}{l}\mathrm{X}^{2}= \\
(\mathrm{Fi}-\mathrm{Pi})^{2} / \mathrm{Pi}\end{array}$ \\
\hline 1 & 3132 & 3132 & 0 & 0.00000 & 0.00000 \\
2 & 340 & 350 & -10 & 98.56118 & 0.28166 \\
3 & 65 & 97 & -32 & 1029.93026 & 10.60772 \\
4 & 28 & 39 & -11 & 123.12683 & 3.14933 \\
5 & 14 & 19 & -5 & 28.16200 & 1.45866 \\
6 & 7 & 11 & -4 & 14.80572 & 1.36486 \\
7 & 2 & 7 & -5 & 21.74213 & 3.26319 \\
8 & 1 & 4 & -3 & 11.34405 & 2.59703 \\
9 & 1 & 3 & -2 & 4.03964 & 1.34212 \\
12 & 1 & 1 & 0 & 0.04494 & 0.03708 \\
13 & 1 & 1 & 0 & 0.00348 & 0.00370 \\
17 & 1 & 0 & 1 & 0.35653 & 0.88490 \\
Total & 3593 & 3665 & -1487 & 1332.11676 & 24.99024 \\
\hline
\end{tabular}

flipped classroom literature. We can, therefore, conclude that author productivity in this research area fits Lotka's law.

\section{Discussion}

This section discusses the findings above by revisiting the following research questions (RQs).

- RQ1: What is the current state of the publication in the flipped classroom?

The selection of articles between the year 2012 until early of 2020 in this bibliometric analysis is a timely undertaking as it gauges the extent to which the momentum of flipped classroom application during the second decade of the new millennium heading forward for the next decades of the millennium. Based on the analysis done, it suggests that flipped classroom or flipped learning strategy/approach is increasingly capturing attention by the growing number of practitioners, researchers and scholars for the next coming decades.

The analysis also successfully revealed the shift in the participation of developing countries in this kind of research. In the work of Yang et al. (2017), who analysed this field between 2000 and 2015, the United States and other Western countries acted as the dominant countries in researching flipped classroom. As this present study shows, the research outputs from developing countries are picking up momentum leaving their 
precedented comrades behind with a justifiable gap - the rise in the educational technology in these developing countries since the beginning of the second decade.

Based on the growth presented in the tables and figures in the previous sections, the trend of using flipped classroom seems to be opted by many in future. This is anticipated due to the mushrooming of the technology-based education that came as a saviour, in particular, during times of hardship when synchronous or face to face physical meetings are not available or could not be implemented. Exemplifying this is the current pandemic of COVID-19 that urges for emergency remote teaching globally.

- RQ2: What are the current citation patterns of publication on the flipped classroom?

To date, based of the 1557 documents gathered from the Scopus database, a total of 12,190 citations have been obtained representing a total of 1523.75 citations per year, 7.83 number of citations per paper, 512.53 papers per author and 2.76 authors per paper. However, out of the number of 1557 documents, only 889 documents have been cited so far. The studies on flipped classroom also have reached $48 \mathrm{~h}$-index and $89 \mathrm{~g}$-index at the time this data was analysed. The article by Bishop and Verleger (2013) has so far received the highest number of citations within flipped classroom studies.

- RQ3: Which themes involving the flipped classroom are the most popular among scholars?

This paper found four themes based on the analysis of the co-occurrences of the keywords, namely flipped classrooms, human, nursing education and student-centred learning. However, based on the analysis on the occurrences of term on the title and abstract from the Scopus database, there are five clusters found in this visualisation map. These themes were grouped as student engagement group as theme one, teaching model group as theme two, classroom method as theme three, assessment group as theme four, and completion group as theme five. Based on the analysis, it is suggested these themes are the centre of the studies in the flipped classroom.

- RQ4: What is the authorship pattern of the publication on the flipped classroom, and how does this pattern distribution fit into Lotka's Law?

Generally, most of the previous bibliometric analysis articles reported on the common variables which are also presented in this study. As noted, this study puts more emphasis on the analysis of the authors' productivity pattern. This decision was based on the premise that the future navigation of flipped classroom literature greatly depends on the contribution and commitment of existing and future authors who are also the practitioners or the advocators of the flipped classroom.

It is noteworthy that the trend of other variables greatly depends on the commitment of the authors in publishing future articles. In other words, an author contribution prediction is significant in gauging the degree of commitment for an author to be potentially published in similar literature in future. 
Lotka's law was employed alongside the bibliometric authorship analysis to predict the future of the literature. Based on the results, the pattern distribution of the author's contribution fits with Lotka's Law. Both K-S and Chi-square have confirmed the applicability of Lotka's law and found that this law fit the author distribution in flipped classroom studies. With this finding, it is predicted that more enthusiastic authors will come up with more articles on flipped classroom/learning in future decades.

This observation is hoped to expedite the application of flipped classroom in the era of volatility, uncertainty, complexity and ambiguity (VUCA) of educational settings. As aforementioned, the exemplary COVID-19 pandemic currently reinforces schools and higher education providers to opt for emergency remote online learning. However, how does this enforcement associate with flipped strategy? This question promises future avenue for flipped learning research.

- RQ5: What areas involving flipped classroom need additional studies?

From the above discussion, we see that the VUCA circumstance such as COVID-19 pandemic as supporting flipped learning as more teachers are using videos to teach remotely from home. Some of them even recorded their teachings and posted to YouTube, or any other channels (e.g., social media like Telegram or WhatsApp) to aid those with low bandwidth internet capacity. This method is seen as allowing for mastery learning for students whereby students could replay the video at their own pace.

However, as the flipped approach emphasis on teacher facilitation during the in-class session, there is a concern on how the face-to-face facilitation is to occur when no physical meetings are available during an online class. With regard to this scenario, it opens up the opportunity for more diversified definition and application of flipped classroom or flipped learning due to the flexibility and adaptability of flipped classroom conception at the critical age of pandemic. Hence, potential rooms for researching the virtual in-class strategies of the flipped classroom are plenty. For instance, how teachers facilitate their students' homework or tutorial in a virtual session via the synchronous approach is something worth investigating.

Of equal importance is the monitoring effort and mechanism that a teacher must labour as to ensure learning engagement on students' part (Kushairi 2016, 2018). This also implies the critical aspect of researching how teachers see themselves as a lifelong learner which places teachers to learn, unlearn and relearn to make them continuously relevant within the uncertainties of educational settings (Kushairi 2010). The scenario indicates the potential of continuous professional development programs to be provided by educational and training providers. Areas such as competency in ICT, educational technology, remote teaching, remote learning, remote assessment, online monitoring, online coaching, online facilitation, online motivation support, so on and so forth are waiting to be extensively ventured beyond the current applications in this decade. This argument entails rooms for exploring and venturing into possibilities of diversifying the flipped classroom approaches. 


\section{Conclusion}

This study aims to examine the trend of research on flipped classroom by looking into the current state of publication, the pattern of citations, presenting the theme involved, test the applicability of Lotka's law and propose the areas for future research in the flipped classroom. This paper adopts the bibliometric approach by presenting the quantity (i.e. the number of publications by year, document types, number of publication by source title, source type, number of publication by country, number of publication by institution, languages and subject area), quality (such as the number of citations and citation metrics) and structural map for the data gathered from the Scopus database. The findings presented here cover the data obtained from the Scopus database only. The data were pooled from searches using keywords "flipped learning" and "flipped classroom", extracting data only under the "title of the article'. Further research can be expanded into other fields, such as abstract and keywords. However, this requires more detail screening and filtering.

It is noteworthy that this paper significantly differs from any other bibliometric analysis on flipped classroom literature thus far, as it had employed Lotka's law. Aiming at testing the author's productivity, the Lotka's Law serves to be more significant in predicting the trend of research publications in flipped classroom studies. The over-arching goal is to predict the survival of authors and its publication to the body of knowledge pertaining to curriculum and instruction field as 'flippers' (a term that we finally subscribed to denote practitioners of the flipped classroom), took up multiple roles while conducting flipped learning-as a practitioner, researcher, scholar and co-learner, simultaneously. Hence, teachers and educators who constantly changed their pedagogical strategies and approaches within the dynamic emergence of educational technology have proved themselves as true lifelong learners.

This study's results will help specific researchers understand the worldwide success of flipped classroom learning and propose pathways for further studies. It suggests that flipped classroom will continue to become popular for the next decades due to the mushrooming of technology which has widened up the participation in learning and narrowed down the access gap amongst students. This proves that technology plays an important enabler. However, alongside the technology advancement that expedites the acceptance of Flipped classroom approach by many, the emergence of electronic data threat due to electronic ubiquity have inevitably exposed many educators and students to VUCA situations. The cases of cybersecurity breach happening in other fields of education signify the fragility of students' and educators' database captured during the flipped classroom approach. The signing up of certain application for web-based online learning tools and completing the profile via digital platform exposed the users towards the cyber threat.

Even though no cases have been reported in any literature in the flipped classroom so far, it is the area that needs more attention from the researchers and practitioners. With a pool of committed researchers, scholars as well as educators that Lotka's Law has predicted in this study, the literature in the flipped classroom will presumably survive in contributing to combat the potential difficulties arise in the educational setting in future. This marks the avenue of future research. 


\section{References}

Abeysekera, L., \& Dawson, P. (2015). Motivation and cognitive load in the flipped classroom: Definition, rationale and a call for research. Higher Education Research \& Development, 34(1), 1-14. https://doi.org/ $10.1080 / 07294360.2014 .934336$.

Adigwe, I. (2016). Lotka's law and productivity patterns of authors in biomedical science in Nigeria on HIV/ AIDS. The Electronic Library., 34, 789-807. https://doi.org/10.1108/EL-02-2014-0024.

Ahmi, A., Elbardan, H., \& Raja Mohd Ali, R. H. (2019). Bibliometric Analysis of Published Literature on Industry 4.0. In 2019 International Conference on Electronics, Information, and Communication (ICEIC) (pp. 1-6). IEEE. https://doi.org/10.23919/ELINFOCOM.2019.8706445

Ahmi, A., Saidin, S. Z., Mohd Nasir, M. H., \& Ismail, Z. (2020). Applicability of Lotka's law in eXtensible business reporting language (XBRL) studies. International Journal of Advanced Science and Technology, 29(6), 282-289.

Al-Shabibi, T. S., \& Al-Ayasra, M. A. K. (2019). Effectiveness of the flipped classroom strategy in learning outcomes (Bibliometric study). International Journal of Learning, Teaching and Educational Research, 18(3), 96-127. https://doi.org/10.26803/ijlter.18.3.6.

Baker, H. K., Pandey, N., Kumar, S., \& Haldar, A. (2020). A bibliometric analysis of board diversity: Current status, development, and future research directions. Journal of Business Research, 108, 232-246. https:// doi.org/10.1016/j.jbusres.2019.11.025.

Bastian, M., Heymann, S., \& Jacomy, M. (2009). Gephi: An open source software for exploring and manipulating networks. International AAAI Conference on Weblogs and Social Media. https://gephi. org/users/publications/.

Bergmann, J., \& Sams, A. (2012). Flip your classroom: Reach every student in every class every day. Washington, DC: International Society for Technology in Education.

Bhagat, K. K., \& Spector, J. M. (2018). A bibliometric analysis of six years of research on flipped classroom. In 2018 IEEE 18th International Conference on Advanced Learning Technologies (ICALT) (pp. 27-29). IEEE. https://doi.org/10.1109/ICALT.2018.00013.

Bishop, J. L., \& Verleger, M. A. (2013). The flipped classroom: A survey of the research. In ASEE national conference proceedings, Atlanta, GA 30(9), 1-18.

Burnham, J. F. (2006). Scopus database: A review. Biomedical digital libraries, 3(1), 1. https://doi.org/10. $1186 / 1742-5581-3-1$.

Burns, J. (2012). Critical care in the age of the duty hour regulations: Circadian-based scheduling, standardised handoffs, and the flipped classroom? Critical Care Medicine, 40(12), 3305-3306. https://doi.org/10.1097/ CCM.0b013e31826bf117.

Chen, H., \& Ho, Y. S. (2015). Highly cited articles in biomass research: A bibliometric analysis. Renewable and Sustainable Energy Reviews, 49, 12-20. https://doi.org/10.1016/j.rser.2015.04.060.

Chiu, W. T., \& Ho, Y. S. (2007). Bibliometric analysis of tsunami research. Scientometrics, 73(1), 3-17. https://oi.org/10.1007/s11192-005-1523-1.

Chuang, K. Y., Huang, Y. L., \& Ho, Y. S. (2007). A bibliometric and citation analysis of stroke-related research in Taiwan. Scientometrics, 72(2), 201-212. https://doi.org/10.1007/s11192-007-1721-0.

Coile, R. C. (1977). Lotka's frequency distribution of scientific productivity. Journal of the American Society for Information Science, 28(6), 366-370.

Comerio, N., \& Strozzi, F. (2019). Tourism and its economic impact: A literature review using bibliometric tools. Tourism Economics, 25(1), 109-131. https://doi.org/10.1177/1354816618793762.

Dong, B., Xu, G., Luo, X., Cai, Y., \& Gao, W. (2012). A bibliometric analysis of solar power research from 1991 to 2010. Scientometrics, 93(3), 1101-1117. https://doi.org/10.1007/s11192-012-0730-9.

Falagas, M. E., Pitsouni, E. I., Malietzis, G. A., \& Pappas, G. (2008). Comparison of PubMed, Scopus, web of science, and Google scholar: Strengths and weaknesses. The FASEB Journal, 22(2), 338-342.

Flumerfelt, S., \& Green, G. (2013). Using lean in the flipped classroom for at risk students. Journal of Educational Technology \& Society, 16(1), 356-366.

Forsey, M., Low, M., \& Glance, D. (2013). Flipping the sociology classroom: Towards a practice of online pedagogy. Journal of Sociology, 49(4), 471-485.

Gilboy, M. B., Heinerichs, S., \& Pazzaglia, G. (2015). Enhancing student engagement using the flipped classroom. Journal of Nutrition Education and Behavior, 47(1), 109-114. https://doi.org/10.1016/j.jneb. 2014.08.008.

Jensen, J. L., Kummer, T. A., \& Godoy, P. D. D. M. (2015). Improvements from a flipped classroom may simply be the fruits of active learning. CBE-Life Sciences Education, 14(1), ar5. https://doi.org/10.1187/ cbe.14-08-0129. 
Kim, M. K., Kim, S. M., Khera, O., \& Getman, J. (2014). The experience of three flipped classrooms in an urban university: An exploration of design principles. The Internet and Higher Education, 22, 37-50. https://doi.org/10.1016/j.iheduc.2014.04.003.

Kumar, A. (2019). An examination of Lotka's law \& Author's productivity in the field of supply chain management. $\log$ Forum, 15(4), 50-520.

Kushairi, N. (2010). Understanding teachers' identity as learners: The case of Malaysian teachers. Unpublished doctoral thesis. England: University of Bristol.

Kushairi, N. (2016). 'PEEP': Harnessing pastoral care to assist students' learning via digital support. Jurnal IPDA, 23, 137-149.

Kushairi, N. (2018). PEiEP via flipped: How teachers can support learning engagement? Prosiding Kolokium Pengurusan dan Kepimpinan Pendidikan 2018. https://iab.moe.edu.my/bahanportal/penerbitan/Buku\% 20ProsidingKolokium2018_2.pdf; http://il2018.blogspot.com/p/abstraks.html.

Lage, M. J., \& Platt, G. (2000). The internet and the inverted classroom. Journal of Economic Education, 31(1), 11. https://doi.org/10.1080/00220480009596756.

Lotka, A. J. (1926). The frequency distribution of scientific productivity. Journal of the Washington Academy of Sciences, 16(12), 317-323.

Luker, C., Muzyka, J., \& Belford, R. (2015). Introduction to the spring 2014 ConfChem on the flipped classroom. Journal of Chemical Education, 92(9), 1564-1565. https://doi.org/10.1021/acs.jchemed. $5 \mathrm{~b} 00024$.

McDonald, K., \& Smith, C. M. (2013). The flipped classroom for professional development: Part I. benefits and strategies. The Journal of Continuing Education in Nursing, 44(10), 437-438. https://doi.org/10. 3928/00220124-20130925-19.

McLaughlin, J. E., Roth, M. T., Glatt, D. M., Gharkholonarehe, N., Davidson, C. A., Griffin, L. M., Esserman, D. A., \& Mumper, R. J. (2014). The flipped classroom: A course redesign to foster learning and engagement in a health professions school. Academic Medicine, 89(2), 236-243. https://doi.org/10. 1097/ACM.0000000000000086.

Missildine, K., Fountain, R., Summers, L., \& Gosselin, K. (2013). Flipping the classroom to improve student performance and satisfaction. Journal of Nursing Education, 52(10), 597-599.

Naheem, K. T., Sivaraman, P., \& Saravanan, G. (2019). Application of Lotka's law in Bell's palsy (facial paralysis) research output during 2004-2018. Library Philosophy and Practice, University of Nebraska, Lincoln libraries, 2019, pp.2892.

Nicholls, P. T. (1986). Empirical validation of Lotka's law. Information Processing \& Management, 22(5), 417-419.

Nwagwu, W. E. (2007). A comparative study of the productivity of HIV/AIDS literature on Nigeria and South Africa in Medline and science citation index. African Journal of Library, Archives \& Information Science, 17(1), 1-13.

O'Flaherty, J., \& Phillips, C. (2015). The use of flipped classrooms in higher education: A scoping review. The Internet and Higher Education, 25, 85-95. https://doi.org/10.1016/j.iheduc.2015.02.002.

Pao, M. L. (1985). Lotka's law: A testing procedure. Information Processing \& Management, 21(4), 305-320. https://doi.org/10.1016/0306-4573(85)90055-X.

Parslow, G. R. (2012). Commentary: The khan academy and the day-night flipped classroom. Biochemistry and Molecular Biology Education, 40(5), 337-338.

Pierce, R., \& Fox, J. (2012). Vodcasts and active-learning exercises in a "flipped classroom" model of a renal pharmacotherapy module. American Journal of Pharmaceutical Education, 76(10), 1-5. https://doi.org/ 10.5688/ajpe7610196.

Prober, C. G., \& Heath, C. (2012). Lecture halls without lectures - A proposal for medical education. New England Journal of Medicine, 366(18), 1657-1659.

Rathika, N., Thanuskodi, S., \& Sudhakar, K. (2020). Lotka's law and the pattern of scientific productivity in the marine pollution research. International Journal on Emerging Technologies, 11(2), 332-341.

Sedighi, M. (2016). Application of word co-occurrence analysis method in mapping of the scientific fields (case study: The field of Informetrics). Library Review, 65(1/2), 52-64. https://doi.org/10.1108/lr-072015-0075.

Smit, K., de Brabander, C. J., \& Martens, R. L. (2014). Student-centred and teacher-centred learning environment in pre-vocational secondary education: Psychological needs, and motivation. Scandinavian Journal of Educational Research, 58(6), 695-712.

Smith, C. M., \& McDonald, K. (2013). The flipped classroom for professional development: Part II. Making podcasts and videos. The Journal of Continuing Education in Nursing, 44(11), 486-487. https://doi.org/ 10.3928/00220124-20131025-93. 
Sweileh, W. M., Al-Jabi, S. W., AbuTaha, A. S., Zyoud, S. H., Anayah, F. M. A., \& Sawalha, A. F. (2017). Bibliometric analysis of worldwide scientific literature in mobile - health: 2006-2016. BMC Medical Informatics and Decision Making, 17(1), 72. https://doi.org/10.1186/s12911-017-0476-7.

Tucker, B. (2012). The flipped classroom: Online instruction at home frees class time for learning. Education Next, 12(1), 82-83.

Tune, J. D., Sturek, M., \& Basile, D. P. (2013). Flipped classroom model improves graduate student performance in cardiovascular, respiratory, and renal physiology. Advances in Physiology Education, 37(4), 316-320. https://doi.org/10.1152/advan.00091.2013.

Van Eck, N. J., \& Waltman, L. (2020). VOSviewer Manual. version 1.6.15. Leiden: University Leiden.

Wen, H., \& Huang, Y. (2012). Trends and performance of oxidative stress research from 1991 to 2010. Scientometrics, 91, 51-63. https://doi.org/10.1007/s11192-011-0535-2.

Wolbrink, T. A., \& Burns, J. P. (2012). Internet-based learning and applications for critical care medicine. Journal of Intensive Care Medicine, 27(5), 322-332. https://doi.org/10.1177/0885066611429539.

Yang, L., Chen, Z., Liu, T., Gong, Z., Yu, Y., \& Wang, J. (2013). Global trends of solid waste research from 1997 to 2011 by using bibliometric analysis. Scientometrics, 96(1), 133-146. https://doi.org/10.1007/ s11192-012-0911-6.

Yang, L., Sun, T., \& Liu, Y. (2017). A Bibliometric investigation of flipped classroom research during 20002015. International Journal Of Emerging Technologies In Learning (IJET), 12(06), 178-186. https://doi. org/10.3991/ijet.v12i06.7095.

Yi, H., \& Xi, Z. (2008). Trends of DDT research during the period of 1991 to 2005. Scientometrics, 75(1), 111-122. https://doi.org/10.1007/s11192-007-1828-3.

Publisher's note Springer Nature remains neutral with regard to jurisdictional claims in published maps and institutional affiliations.

\section{Affiliations}

\section{Norliza Kushairi $^{1} \cdot$ Aidi Ahmi $^{2}$}

1 School of Education, Universiti Utara Malaysia, 06010 UUM Sintok, Kedah, Malaysia

2 Tunku Puteri Intan Safinaz School of Accountancy, Universiti Utara Malaysia, 06010 UUM Sintok, Kedah, Malaysia 